\section{Societies and Academies}

\section{London}

Royal Society (Proc. A., 165, 313-452; April 14, 1938).

E. A. Mrlne : On the equations of electromagnetism. (1) Identifications. (2) Field theory.

H. J. Gouch and W. A. Woon: Crystalline structure of steel at fracture.

Edmund C. Stoner: Collective electron ferromagnetism.

W. MANDELL : Resonance in erystal beams of sodium-ammonium seignette salt.

R. B. Randall, M. Benger and C. M. Groocock : Alkaline permanganate oxidation of organic sub. stances selected for their bearing upon the chemical constitution of coal.

\section{Paris}

Academy of Sciences, March 14 (C.R., 206, 793-864).

Gabriel Bertrand and Lazare Silberstein : The distribution of boron in the organs of the white lily. The amount of boron in the plant as a whole is small compared with other plants : it is lowest in the stem and highest in the reproductive organs.

Pierre lejay and Chang Hung Chi : Gravimetric chart of the south of China.

Etimnne Halphen: Research on the most independent chance variables.

Aryen Dvoretzky : The geometrical basis of the theorem of M. Mandelbrojt and analogous theorems.

BÉLA DE Sz. NAGY : The extremal properties of Fourier series transformed by absolutely monotonic series.

Kwor-Prng LEe : The Borel directions of meromorph functions of finite order higher than $1 / 2$.

CARLOS BiggerI : The singular points of a Taylor's series external to the circle of convergence.

Georges Dedebant, Michel Krveliovitch and Philippe Werrle: A method of establishing the equations of hydrodynamics.

Louis VIAUD : An experimental method for the study of an air blast in interaction with the soil.

M. and Mme. Lucien D'Azambuja : The velocity of rotation of solar prominences deduced from their successive passages on the central meridian of the star.

PaUl Muliser : A new double refracting prism and its application to the measurement of double stars.

V. Frouow: The analysis of the maregraphic series of Norway.

René Lucas : New properties of double refraction of liquids submitted to ultra-sounds. A column of liquid, placed between Nicol prisms set to extinction, shows reappearance of light when the liquid is submitted to ultra-sounds produced by piezo-electric quartz. These optical effects are very clear with some liquids (castor oil, linseed oil) but are inappreciable with others (glycerol, ethyl acetate).

GeORges DechêNE : The capacity at the contact of a metal with a semi-conductor.

Frantz Perrier : The determination of the wavelengths of the radiation emitted by electrified insulators : an attempt at a theoretical interpretation. From the measurement of the absorption coefficients in celluloid it is shown that the frequency of the radiation is proportional to the potential difference between the two faces of the dielectric.

Mme. Thériese Grivet-Meyer : Some properties of the penetrating fraction of the cosmic radiation. The properties of the hard variation vary with the thickness of the total screen interposed. It is not possible to represent the absorption of the radiation by a simple exponential.

Ladislas Goldstein and Anatole Rogozinskr : The use of an ionization chamber with a liquid dielectric for the study of neutrons.

Marcus Brutzcus : The thermochemistry of the sulphur compounds.

Mlle. Yvonne Garreau : The constitution of some compounds formed by the oxidation of hydroquinone in the presence of ammonium sulphite or of primary amines.

Tryphon Karantassis and Constantin VassILIADÈs : New oxyiodine compounds of the dialkyl derivatives of tin.

JEAN VÈnE : Syntheses starting from the bisulphite derivatives of the camphoric $\beta$-aldehyde esters.

Henri Longchambon: Cordierite gneiss and granites in the French Central Massif.

Gilbert Mathieu : The structure of the island of Yeu.

Louis Eblé and Gaston Gibault : The values of the magnetic elements at the Observatory of Chambon-la-Forêt (Loiret) on January 1, 1938.

Georges Dubois and Mme. Camille Dubois : The peats of Cragou (Finistère). Results of pollen analyses: the Cragou peat is relatively recent, neolithic.

Georges Deflandre: Study of the organic materials forming certain fossil plankton microorganisms. Attempts at microchemical analysis. Results of the application of various staining reagents. The present ideas on the microchemistry of cellulose membranes, or of similar composition, based on the study of existing bodies or living beings, cannot be applied to plankton microfossils.

Mlle. Marie CelaA : The structure of the central cells of Halopitys pinastroides.

ARthur BrUNEL : The degradation of substances of puric origin in the lamellibranch molluses. Mytilus edulis possesses the property of degrading uric acid to urea and ammonia: allantoin and allantoic acid are the intermediate terms of this reaction.

Michel Machebeuf and Francis Tayeau: The state of the lipids and of cholesterol in the blood serum: the destruction of certain lipidoproteinic cenapses and the liberation of their lipoid substances by a soap.

Gustave Guittonneau and René Chevalier : The attack of the benzene nuclei and the utilization for food of phenol by the Azotobacter of the soil. A strain of Azotobacter has been cultivated which grows on silicogel containing phenol, and which also grows on media containing mannitol, sodium benzoate, sodium $p$-oxybenzoate, but does not develop in the presence of $m$-oxybenzoate or $o$-oxybenzoate. This would appear to be a new physiological type of Azotobacter.

\section{Moscow}

Academy of Sciences (C.R., 18, No. 2, 1938).

S. Sobolev : A class of integro-differential equations with several independent variables. (2).

K. PersidskiJ : The law of large numbers.

K. BRoDovitskiJ : Statistical analysis of the rhythm of fundamentally unobservable regularities, observed manifestations of which are subject to some unknown perturbations. 
I. M. Goldman : Breakdown of compressed nitrogen in small gaps.

E. Gross : The splitting-up of the Rayleigh line and the acoustic spectrum of crystals.

P. Petrenko-Kirirschenko : The law of periodicity.

M. V. GoRLENKo : Resistance of winter wheats to black bacteriosis (Bacterium translucens var. undulosum S.J.R.).

A. A. Isakova and A. A. Andrejev : The excretion of nitrogenous compounds by the roots of leguminous plants (lupin) and the conversion of these compounds in the presence of bacteria.

M. Aвакumova : Problem of photo-periodical and temperature after-effects.

V. G. Alersandrov and O. G. Aleksandrova : The flintiness and flouriness of wheat endosperm.

N. G. CHLOPIN : Attempt at an experimental analysis of the auxiliary components of the nervous system.

J. A. VINNIKov: Growth and transformation in vitro of myoneural elements (sphincter and dilator of the iris).

V. P. Michailov : Growth and transformation in vitro of the covering cells of the vascular plexuses of the brain.

N. N. KANNEGISSER : Growth and transformation in vitro of the elements of the pia mater.

G. A. SchмidT : Ectoderm of the Anuran gastrula under the inductive influence of dead organizers and parts of organs of Amphibia and mammals.

\section{Tokyo}

Imperial Academy (Proc., 14, No. 2, 27-85, Feb. 1938).

S. KakUtani : The uniqueness of Haar's measure. Shin-rchr Izumi and Tatsuo Kawata: Notes on Fourier series. (3) Absolute summability.

Hiтоsнr Homsu : The projective theory of 'paths' of the third order

$$
x\left({ }^{3}\right)^{i}+H^{i}\left(x, x\left({ }^{1}\right), x\left({ }^{2}\right)\right)=0 .
$$

KENZO JOH : A theorem of K. Löuner on univalent functions.

Masao Sugawara : Siegel's modular function of the higher degree.

Hantaro Nagaoka and Tadao Mishima: High terms of Paschen series in hydrogen and deuterium.

Ken Sugawara: Decompositions in shallower waters of a lake in summer and the supply of oxygen from the atmosphere.

Masao Kubokawa: Activated adsorption of methane on reduced nickel.

ShigehiKo Sugasawa, Küchiro Kakemi and TôRu Tsuda : Synthesis of 6,7-dimethoxyquinoline.

Hidekichi Yanagisawa and Eüchi Yokor : Purification of hirudin, an active principle of Hirudo medicinalis.

TeÜCHI KoBayashi and HISAShr Mochizuki : Outline of the structure of the Kibi plateau on the inner side of western Japan.

SABURô ÔISHI : The Japanese equivalents of the Lepidopteris and Thaumatopteris zones of East Greenland.

GiHer YaKama : (1) Hydrogen ion concentration, etc., of the anther sap of Lilium species. (2) Potential measurements of the dividing pollen mother cells of Lilium speciosum.

\section{Forthcoming Events}

[Meetings marked with an asterisk are open to the public.]

\section{Monday, May 16}

King's College, London, W.C.2, at 5.30.-Prof. Th. J. Stomps: "Recent Developments of the Mutation Theory".*

\section{Wednesday, May 18}

Royal Society of ARts, at 8.30.-Prof. K. W. Braid: "Bracken and its Present Menace to Heather and Pasture".

\section{Thursday, May 19}

Royal Socrety, at 2.30.-Discussion on Turbulence in Fluid Motions, to be opened by Prof. G. I. Taylor, F.R.S.

London Mathematical Society (at the Royal Astronomical Society, Burlington House, W.1), at 5.-Prof. W. V. D. Hodge : "Harmonic Integrals",

British Institute of Radiology, at 6.30.-Annual General Meeting.

Sir John Cass Technical Institute, Aldgate, London, E.C., at 7.-A. J. Murphy : "The Selection of NonFerrous Materials for Engineering Purposes" (succeeding lectures on May 26 and June 2).*

Chemical Societr, at 8.-Discussion on "Organic Intermolecular Complexes". Opened by Prof. G. M. Bennett.

\section{Appointments Vacant}

APPLICATIONs are invited for the following appointments, on or before the dates mentioned :

Assistant Enginene and Crvil EngInemeing Assistants in the Roads Department of the Ministry of Transport-Assistant Secretary, Establishment Department, Ministry of Transport, Metropole Build: ings, Northumberland Avenue, W.C.2 (May 16).

LECTURER IN MatheMatics (woman) in Darlington Training College -Principal (May 18).

SENIOR ScIENTIFIC OFFICER in the Directorate of Civil Research and Production, Air Ministry-Permanent Under-Secretary of State, Air Ministry (S.2.d.), Adastral House, Kingsway, W.C.2 (May 20).

SCIENTIFIC OFFICER, JUNIOR SCIENTIFIC OFFICER, TECHNICAL OFFICERS and ASSISTANTS (II) for work on wireless apparatus, etc., at the Signals Experimental Establishment, Woolwich, S.E. 18--Superintendent (May 20).

LeCTURER IN PHYsiology in the University of Queensland-The Secretary, Universities Bureau of the British Empire, 88A, Gower Street, London, W.C.1 (May 20).

assistant lecturer in Chemical Pathology in the University of Manchester-Registrar (May 21).

SENIOR SCIENTIFIC OFFICER in the Admiralty scientifle pool (physics, particularly acoustics) - Secretary to the Admiralty (C.E. Branch) quoting Ref. No. C.E. 3326/38 (May 21).

Lectorers in Mathematros, Physics, Chemstri, and Civil and Mechanical Engineering Department of Woolwich Polytechnic, S.E.18 - Secretary (send stamped addressed envelope) (May 21).

Two Assistants (one with knowledge of aeronautics) in the CrviL AND MECHANICAL ENGINEERING DEPARTMENT, a LECTURER IN Polytechnic, St. John Street, London, E.C.1-Secretary (May 23).

LECTURER IN ZOOLOAY in King's College, Newcastle-upon-TyneThe Acting Secretary to the Council (May 25).

Pathologist AND BACTERIologist at the Memorial Ophthalmic Laboratory, Cairo-Horace $\mathbf{H}$. Rew, Examination Hall, Queen Square, London, W.C.1 (May 28).

Head of the Department of Physics at the Chelsea Polytechnic, London, S.W.3-Principal (May 28).

ChEMISTs in the War Department-Under-Secretary of State (C.5), War Office, S.W.1, quoting Appts./83 (May 28).

IfCTURer in Mathematics and Lecturer in Chemistry in the Derby Technical College-Clerk to the Governors (May 28)

Assistant METEOROLOGIST in the Meteorological Service of the Sudan Government-The Controller, Sudan Government, London Office, Wellington House, Buckingham Gate, London, S.W.1 (May 31). BACTERIOLOGIST in the Veterinary Department in Kenya-Director of Recruitment (Colonial Service), 8 Buckingham Gate, London, S.W.1 (May 31).

Demonstrator in The Department of Zoology at Bedford College for Women, Regent's Park, N.W.1--Secretary (May 31).

LECTURER IN THE SCHOOL OF AGRICULTURE near KhartoumUniversity Appointments Board or Controller, Sudan Government (London Office), Wellington House, Buckingham Gate, S.W.1, marking envelope "Lecturer" (May 31). 